University of Nebraska - Lincoln

DigitalCommons@University of Nebraska - Lincoln

$10-2010$

\title{
Ecological risk assessment should be value-relevant but not value-biased
}

Peter Calow

Roskilde University, pcalow2@unl.edu

Valery E. Forbes

University of Nebraska-Lincoln, veforbes@umn.edu

Follow this and additional works at: https://digitalcommons.unl.edu/biosciforbes

Part of the Pharmacology, Toxicology and Environmental Health Commons

Calow, Peter and Forbes, Valery E., "Ecological risk assessment should be value-relevant but not valuebiased" (2010). Valery Forbes Publications. 11.

https://digitalcommons.unl.edu/biosciforbes/11

This Article is brought to you for free and open access by the Papers in the Biological Sciences at DigitalCommons@University of Nebraska - Lincoln. It has been accepted for inclusion in Valery Forbes Publications by an authorized administrator of DigitalCommons@University of Nebraska - Lincoln. 


\title{
Ecological risk assessment should be value-relevant but not value-biased
}

\author{
Peter Calow and Valery Forbes \\ Roskilde University, Roskilde, Denmark \\ Corresponding author - Valery Forbes
}

To be useful in informing environmental management decisions, ecological risk assessments (ERAs) need to be expressed in value-relevant terms (USEPA 2009). Making decisions about accepting more or less ecological resources for more or less economic and social gain depends upon public values. ERAs have been criticized for not delivering value-relevant results and for therefore not being useful as a basis for management decisions (Gibbs 2010). We agree that ERAs need to be value-relevant, but we also must be explicit about what constitutes science and what constitutes values in this process. In a recent editorial, Backhaus et al. (2010) discuss the pressures faced by scientists to mix science with values when performing risk assessments and stress the importance of resisting the allure of so-called normative science. We strongly support this view. Public values are not a part of science, and the values of scientists do not necessarily reflect the values of the public. Here we elaborate on these two good reasons for keeping science and values separate in environmental decision making.

First, science ideally should strive to separate understanding from values. Hypotheses are based on judgments about how we think the natural world works; but the key to science is that these ideas, or hunches, are confronted with carefully collected evidence from contrived and controlled situations that, at least in principle, are open to checking and repetition by others. The history of science is littered with hypotheses that turned out to be wrong or, if not entirely wrong, were not quite right either. This is why the scientific process seeks to be as rigorous as possible before accepting hypotheses. No doubt the collection of the evidence will be based on judgment and bias (Jasanoff 1990), but the basis of the scientific approach is not to find that acceptable; rather, it is to continually seek to do better through a transparent process of scientific communication involving peer review.

A widespread misconception is that the outputs of science can be treated as if they were certain when developing policy. Understanding environmental problems often involves substantial uncertainties and causal linkages that are enormously complex and not as well understood as they should be. That said, science has delivered spectacularly in terms of visits to the moon, health care, technology that unburdens our lives, and so on; and the basis of this success, in no matter which scientific discipline, whether astrophysics or ecology, is the reliance on evidence rather than on untested hunches. 
One response to perceived limitations of the scientific approach is to explicitly mix evidence-based science and public values in the so-called development of postnormal science (Funtowicz and Ravetz 1990), and some even argue that postnormal approaches should play a key role in training environmental science students for the future (Biggs et al. 2010). Postnormal science has been advocated for deployment when facts are uncertain, stakes high, and decisions urgent. This is manifest in various forms, but a central theme is that the decisions should be based on a dialogue involving an extended community of stakeholders, not just scientists, that bring their own understanding and values into the decision; these are surely the kinds of forums that should be welcome in making decisions. Our concern is not with the process but with what the process is called. To label it as science-even if it is postnormal-is to misunderstand the process of science and potentially undermine what it brings to decision making.

A second reason for maintaining the separation of science and values is to guard against scientists' values dominating policy making. The separation of the judgments of scientists from the evidence-based understanding that they generate is not always understood by the public and decision makers. The problem is that collecting scientific evidence in the face of complexity and uncertainty can be extremely difficult and frustratingly slow; yet the needs of the decision makers are often urgent. The temptation is to take short cuts - to base the decision on less, and less rigorously collected, evidence-and in these very complex circumstances to base decisions on the views of the scientists rather than on the outputs of a thorough, evidence-based process.

This is an aspect of making decisions based on the precautionary principle. Given the enormity of some of the problems being faced in making decisions about complex environmental issues, it is surely legitimate that decision makers sometimes adopt a precautionary approach in the face of so much uncertainty. The key point is that this needs to be done clearly, recognizing that the decisions so made are, by definition, based more on judgment than on evidence, and that as such they may turn out to be wrong and thus bring costs without benefits. A literature is developing that is designed to bring comfort on this point, giving examples of cases where, if the precautionary principle had been applied, the right decisions would have been made (e.g.,
Harremoës et al. 2001); but this is almost bound to be a biased sample because activities and processes deemed to be bad on the basis of the precautionary principle will often be stopped or excluded so that no chance arises to follow up and demonstrate a mistake. Precaution will therefore be an inevitable part of environmental policy and decisions; however, our point is that it should be applied knowingly and transparently, because otherwise it can confuse judgments with evidence-based understanding.

In our view, the best decisions about environmental issues will involve value judgments about public preferences for economic, social, and ecological capital informed by evidence-based science. As such, scientists should be measuring risks on entities that are valued. However, making ERAs value-relevant does not mean mixing values and science.

\section{References}

Backhaus T, Brooks BW, Kapustka L. 20I0. Chemical risk assessment: Pressures, perceptions and expectations. Integr Environ Assess Manag 6:323-324.

Biggs R, Diebel MW, Gilroy D, Kamarainen AM, Kornis MS, Preston ND, Schmitz JE, Uejio CK, van de Bogert MC, Weidel BC, West PC, Zaks DPM, Carpenter SR. 2010. Preparing for the future: Teaching scenario planning at the graduate level. Front Ecol Environ 8:267-273.

Funtowicz SO, Ravetz JR. 1990. Uncertainty and quality in science for policy. Dordrecht (NL): Kluwer Academic. 244 p.

Gibbs MT. 2010. Improving the applicability of quantitative ecological risk assessment tools - Understanding demand-side changes. Human Ecol Risk Assess 16:226-235.

Harremoës P, Gee D, MacGarvin M, Stirling A, Keys J, Wynne B, Guedes Vaz S, editors. 200 I. Late lessons from early warnings: The precautionary principle 1896-2000. Environmental issue report 22. Copenhagen (DK): European Environment Agency.

Jasanoff S. 1990. The fifth branch: Science advisors as policymakers. Cambridge (MA): Harvard Univ.

[USEPA] US Environmental Protection Agency. 2009. Valuing the protection of ecological systems and services. A report of the EPA Science Advisory Board. Washington (DC): EPA-SAB-09-0I2. 